AGRICULTURE AND BIOLOGY JOURNAL OF NORTH AMERICA

ISSN Print: 2151-7517, ISSN Online: 2151-7525, doi:10.5251/abjna.2011.2.12.1437.1444

(C) 2011, ScienceHuß, http://www.scihub.org/ABJNA

\title{
Nutritive values and phytochemical contents of some leafy vegetables grown with different fertilizers Ukpabi Chibueze $^{1}$ and Akubugwo E.I ${ }^{2}$
}

\author{
${ }^{1}$ Science Laboratory Technology Department. Abia State Polytechnic Aba \\ ${ }^{2}$ Biochemistry Department. Abia State University, Uturu
}

\begin{abstract}
The paper discussed the nutritive values and phytochemical contents of Telfaria occidentalis and Talinum triangulare vegetables grown with inorganic and organic fertilizers. The effects of the two application rates $(4.0$ and $8.0 \mathrm{~g} / \mathrm{kg}$ soil) of the fertilizers where examined. The proximate compositions and the phytochemical contents of the vegetables were determined at 12 weeks after planting. The result showed that the nutrient contents of the vegetables varied considerately and the two vegetables recorded highest energy yield in soils treated with pig manure at 4.0 and $8.0 \mathrm{~g} / \mathrm{kg}$ soil fertilizer application rates. Telfaria occidentalis showed step-wise increase in protein contents across the fertilizer application rates of the various fertilizers and decreased in fats and carbohydrate contents. Contrariwise, Talinum triangulare showed similar increase in fats and carbohydrate contents and decrease in protein contents across the fertilizer application rates of the various fertilizers. The result of the phytochemical analysis showed no specific variations across the fertilizer application rates of the various fertilizers. Thus this suggests that fertilizer applications may not have strong influence on the phytochemicals concentrations of vegetables. Saponins, flavonoids, phenols and alkaloids were identified in the sample extract of Telfaria occidentalis, while Tannins were below detection limits of our method. Saponins, flavonoids, phenols, alkaloids and tannins were identified in the sample extract of Talinum triangulare. These results advocate the use of organic fertilizers and that the indigenous leaf vegetables require the urgent application of biotechnology so that the nutritional and phytochemical potentials can be fully exploited.
\end{abstract}

Keywords: Nutritive value, phytochemicals, fertilizers, indigenous leaf vegetables

\section{INTRODUCTION}

Plant produces a great variety of organic compounds that are not directly involved in primary metabolic processes of growth and development (Buchanan et al, 2000). These organic compounds are called secondary metabolites. During metabolism of starch or monosaccharides, carbohydrates are broken down to glycerates, pyruvates and later to acetyl CoA which is finally consumed in tricarboxylic acid cycle. Glycerates and pyruvates, during the course of this breakdown give rise to aliphatic and aromatic amino acids which further produce proteins. Pyruvates are breakdown to acetyl CoA which produces fixed oils and fats through fatty acids. These primary products are termed primary metabolites because of their direct utilization in biological system at the development stages of the plant. (Rangari, 2008). The production of secondary metabolites is mostly dependent on the fundamental processes involved in the biosynthesis of the primary metabolism. Secondary metabolites appear to function primary in defense against predators and pathogens and providing reproductive advantages as attractants of pollinators and seed dispersers (Buchanan et al, 2000).

Reports have shown that the greatest sources of secondary metabolites - phytochemicals are fruit and vegetables (Liu, 2004; Schuppers, 2000). In Southeastern Nigeria, one major constraint affecting crop production is declining soil fertility. The general practice in soil fertility maintenance in crop production in this area has been the traditional shifting cultivation and its related bush fallow rotation system (Oparra Nadi and Okwe, 2000). As a result of increase population, the fallow periods have been drastically reduced and in most places continuous cultivation is practiced (Ano, 2000). Chemical fertilizers, chicken and pig manures are the main fertilizers in use in most places where continuous cultivation is practiced. It is believed that most farmers in Nigeria use excessive rates of inorganic and organic fertilizers due to lack of proper measurement. Secondly, excessive amount of fertilizers are applied to crops, considering that they are reasonably 
Agric. Biol. J. N. Am., 2011, 2(12): 1437-1444

insurances against yield losses and their economic consequences. Another major problem with the indigenous leaf vegetables of Nigeria is that they have not been selected for desirable traits and no serious biotechnological research such as improvement of their nutritional and phytochemical qualities has been done on them. (Adebooye et al 2003; Opabode and Adebooye, 2005).

The medicinal properties of these indigenous leaf vegetables have been documented by a number of researchers (Ayitey - Smith and Addae - Mensah, 1977; Gill, 1992; Benso and Adeyemi, 2007). Fluted pumpkin also known as Telfaria occidentalis is a species of cucurbitaceae family in the tropics and largely consumed in Nigeria. The therapeutic relevance of Telfaria occedentalis has been reported by Mensah et al (2008), and Opabode and Adebooye (2005), in the treatment of Anemia. Fluted pumpkin seed oil has been reported to posses some essential properties (Vitamin A, flavonoids, linoleic acid, oleic acid and alkaloids) which suppress lipid peroxidation, hence improving testicular function (Akintayo, 1997; Bensoussan et al, 1998, Glenville 2006, Akang et al 2010).Water leaf (Talinum trangulare) is considered a cheap crop and can easily be cultivated. Talinum triangulare leaves extract is used as diuretic and in treatment of gastro- intestinal disorder and hypertension (Mensah et al, 2008; Aiyelopa and Bello, 2006). The importance of alkaloids saponins, tannins and flavonoids in various indigenous leaf vegetables used in treating common pathogenic strains has recently been reported by Kubmarawa et al, (2007); Mensah, (2008) and Adekunle and Ikumapayi, (2006).

Hence we need to discover the potentials of our indigenous leafy vegetables in possessing these nutrients and phytochemicals. This will increase the potentials of these indigenous leaf vegetables to serve as supplement for food and also to improve the health status of its consumers. The present study was designed to determine the effect of inorganic and organic fertilizers at different application rates on the nutrient contents and phytochemical compositions of fluted pumpkin and waterleaf vegetables.

\section{MATERIALS AND METHOD}

Planting and harvesting: The Telfaria occedentalis and Talinum trangulare were planted in experimental pots in the green house of the Abia State Polytechnic Aba. Nigeria. The State lies between latitude $4^{0} 45^{1}$ and $6^{0} 15^{1}$ North and longitude $6^{0} 30^{1}$ East. The maximum and minimum temperatures are $31.9^{\circ} \mathrm{C}$ and $22^{\circ} \mathrm{C}$ respectively while the daily sunshine rate in about 4.4 hours. Soil samples were collected from different locations of the Abia State Polytechnic Botanical Garden at a depth of $0-15 \mathrm{~cm}$ into experimental pots. Pin-like size holes were made of the bottom of each experimental pot. The adoption of this mild leaching method was done to reflect the true environmental situation. The soil was a sandy loamy soil.

The soil and fertilizer samples were ground and passed through $2 \mathrm{~mm}$ sieve. The soils were treated with NPK fertilizer, pig and chicken manures, at the rate of $0.0,4.0$ and $8.0 \mathrm{~g} / \mathrm{kg}$ soil respectively. The moisture content of the soil was adjusted at about $70 \%$ of field capacity. The lost water was compensated for by addition of distilled water. The vegetables were planted with respective seeds and were harvested at 12 weeks. The harvested vegetables were sun dried. The samples were ground into uniform powder using an electric machine blender and stored on airtight bottle till required for analysis.

Soil and fertilizer analysis: The soil and fertilizer samples were digested using Nitric acid $\left(\mathrm{HNO}_{3}\right)$ and perchloric acid $\left(\mathrm{HClO}_{3}\right)$ on a hot plate with slight heating at $95^{\circ} \mathrm{C}$ in a fume cupboard. The resultant mixture was digested until a clear digest was obtained and the residue was re dissolve in $2.0 \mathrm{M}$ $\mathrm{HCl}$. Total Nitrogen was determined by macro Kjeldahl method of ASTM (1999) and phosphate content was determined by Ascorbic acid method of APHA (1998). Potassium concentration was also measured by flame photometric method of ASTM (1999). Nitrate $\left(\mathrm{NO}_{3}^{-}\right)$was determined by phenoldisulphonic acid method while Sulphate $\left(\mathrm{SO}_{4}{ }^{2}\right)$ was measured by the turbidimetric method involving the precipitation of barium sulphate,

Nutrient analysis: Proximate chemical composition of each vegetable sample was carried out to determine the moisture, ash, fat, crude fiber, protein and carbohydrate contents of each plant sample according to the method of AOAC (1990) method. The moisture content was determined by drying in an oven at $100^{\circ} \mathrm{C}$ until constant weight, ash by incineration in a muffle furnace at $550^{\circ} \mathrm{C}$ for $48 \mathrm{hrs}$. Proteins by Nitrogen determination using of Macrokjeldahi method and conversion of nitrogen to proteins by the factor 6.25. Fat was by Mullar and Tobin (1980) method, crude fibers by successive digestion of the defatted samples with $0.26 \mathrm{~N}$ sulphuric acid and $0.23 \mathrm{~N}$ potassium hydroxide solutions and carbohydrates by difference method. In 
Agric. Biol. J. N. Am., 2011, 2(12): 1437-1444

this method carbohydrate content is obtained according to Onwuka (2005) calculation equation i.e. $\%$ Available carbohydrates $=100-(\%$ moisture $\%$ Ash $+\%$ protein $+\%$ fiber)

Food energy determination: Food energy measures the chemical energy inherent in the bonds of the organic components of foods. There are two methods of evaluating food energy which include the use of a bomb calorimeter or the calculation of energy from the results of the proximate analysis of the food. The problem with the bomb calorimeter is that it measures the energy of food constituents that may not necessary be oxidized by the human body (mainly the dietary fiber) and therefore over estimates the energy value of the food (James; 1996). Energy value was determined according to the calculation of methods of Okwu and Ukanwa (2007); NIS (2004); Osborne and Voogt (1978) using the equation.

Energy $(\mathrm{KJ} / 100 \mathrm{~g})=4.186\{(\%$ crude protein $\times 4)+(\%$ crude fat $\times 9)+(\%$ carbohydrate $\times 4)\}$.

Phytochemical determination: One gram powder of each of the plant samples was subjected to qualitative phytochemical tests for alkaloids (Wagner dragendroff's regent), saponins (chloroform and $\mathrm{H}_{2} \mathrm{SO}_{4}$ tests), tannins (ferric salt tests) and flavonoid (ammonium test) as adopted by Harborne (1973).

Preparation of fat free samples: $2 g$ each of the samples were defatted with $100 \mathrm{ml}$ of diethyl ether using a soxhlet apparatus for $2 \mathrm{hrs}$.

Alkaloid determination: $5 \mathrm{~g}$ each of the samples were weighed into a $250 \mathrm{ml}$ beaker and $200 \mathrm{ml}$ of $20 \%$ acetic acid in ethanol was added and covered to stand for $4 \mathrm{hr}$. This was filtered and the extract was concentrated using a water- bath to one- quarter of the original volume to the extract until the precipitation was complete. The whole solution was allowed to settle and the precipitate was collected by filtration and weighed. (Harborne, 1973; Obadoni and Ochuko, 2001; Okwu, 2005)

Tannin determination: $5 \mathrm{~g}$ each of the samples were weighed into $100 \mathrm{ml}$ plastic bottle. $50 \mathrm{ml}$ of distilled water was added and shaken for $1 \mathrm{hr}$ in a mechanical shaker. This was filtered into a $50 \mathrm{ml}$ volumetric flask and made up to the mark. Then $5 \mathrm{ml}$ of the filtrate was pipette out into a tube and mixed with $3 \mathrm{ml}$ of $0.1 \mathrm{MFeCl}_{3}$ in $0.1 \mathrm{~N} \mathrm{HCl}$ and $0.008 \mathrm{M}$ potassium ferrocyanide. The absorbance was measured in a photometer at $120 \mathrm{~nm}$ wavelengths, within 10 minutes. A blank sample was prepared and the colour also developed and read using tannin acid to get 100 ppm measured. (Van-Burdan and Robinson, 1981; Okwu, 2005)

Determination of total phenols by spectrophotometeric method: For the extraction of the phenolic component, the fat free sample was boiled with $50 \mathrm{ml}$ of ether for 15 minutes. $5 \mathrm{ml}$ of the extract was pipetted into a $50 \mathrm{ml}$ flask, and then $10 \mathrm{ml}$ of distilled water was added, $2 \mathrm{ml}$ of ammonium hydroxide solution and $5 \mathrm{ml}$ of concentration amyl alcohol were also added. The samples were left to react for 30 minutes for colour development. The absorbance of the solution was read using a spectrophotometer at $505 \mathrm{~nm}$ wavelength. (Harborne, 1973; Obadoni and Ochuko, 2001; Okwu, 2005)

Saponin determination: $5 \mathrm{~g}$ of each of the plant samples were dispersed in $200 \mathrm{ml}$ of $20 \%$ ethanol. The suspension was heated over a hot water bath for $4 \mathrm{hrs}$ with continuous stirring at about $55^{\circ} \mathrm{c}$. The mixture was filtered and the residue re- extracted with another $200 \mathrm{ml}$ of $20 \%$ ethanol. The combined extracts were reduced to $40 \mathrm{ml}$ over water bath at about $90^{\circ} \mathrm{C}$. The concentrate was transferred into a $250 \mathrm{ml}$ separator funnel and $20 \mathrm{ml}$ of diethyl ether was added and shaken vigorously. The aqueous layer was recovered while the ether layer was discarded. The purification process was repeated and $60 \mathrm{ml}$ of $\mathrm{n}$ butanol was added. The combined n-butanol extracts were washed twice with $10 \mathrm{ml}$ of $5 \%$ aqueous sodium chloride. The remaining solution was heated in a water bath. After evaporation the samples were dried in the oven to a constant weight. The saponin content was calculated in percentage (Harborne, 1973; Obadoni and Ochuko, 2001; Okwu, 2005).

Flavonoid determination: $5 \mathrm{~g}$ of each of the plant samples were extracts repeatedly with $100 \mathrm{ml}$ of $80 \%$ aqueous methanol at room temperature. The whole solution was filtered through whatman filter paper No.42 $(125 \mathrm{~mm})$. The filtrate was later transferred into a crucible and evaporated to dryness over a water bath and weighed (Harborne, 1973; Obadoni and Ochuko, 2001; Okwu, 2005).

Statistical analysis: Data for all determinations were subjected to analysis of variance (ANOVA) and significantly different treatment means determined at $5 \%$ level using SPSS for windows (versions 10 and 11). (Pallant 2001)

\section{RESULTS}

Table 1 showed the macronutrient contents of the soil and fertilizers used in the study. The nutrient 
composition and the energy yield of the vegetables at different FARs of the inorganic and organic fertilizers were shown in 2 and 3 . Table 4 and 5 showed the photochemical contents of Telfaria occidentalis and Talinum triangulare treated with inorganic and organic fertilizers at different FARs of 4.0 and $8.0 \mathrm{~g} / \mathrm{kg}$ soil.

Table 1: Some macro nutrient contents of the soil and fertilizers used in the study.

\begin{tabular}{|c|c|c|c|c|}
\hline Parameter(mg/kg) & Method & Soil & CF1 & AM2 \\
\hline Phosphate (P2O5) & APHA 4500-P & $30.0 \mathrm{a}$ & $18,900.0 \mathrm{~b}$ & $19,600.0 \mathrm{C}$ \\
\hline Sulphate (SO42) & ASTM D 516 & $20.0 \mathrm{a}$ & $24.0 \mathrm{~b}$ & $840.0 \mathrm{C}$ \\
\hline Nitrate (NO43) & ASTM D 4500 & $93.0 \mathrm{a}$ & $780.0 \mathrm{~b}$ & $380.0 \mathrm{~d}$ \\
\hline Total Nitrogen & ASTMD 3867 & $621.4 \mathrm{a}$ & $31,236.9 \mathrm{~b}$ & $3,139.4 \mathrm{C}$ \\
\hline Potassium (K) & ASTM D 4191 & $39.76 \mathrm{a}$ & $20,873.0 \mathrm{~b}$ & $1,860.0 \mathrm{~d}$ \\
\hline
\end{tabular}

- Values are means of three determinations.

- $\quad$ Figures followed by the same alphabets are not significantly different but those followed by different alphabets are significantly different.

CF1 is NPK fertilizer while AM1 and AM2 are Pig and chicken manures respectively.

Table 2: Nutritive value and food energy yield of Telfaria occidentalis grown with inorganic and organic fertilizers at different FARs at 12 WAP

\begin{tabular}{|c|c|c|c|c|c|c|c|}
\hline \multicolumn{8}{|l|}{ Nutritive value } \\
\hline Fertilizer type & $\mathrm{CK}$ & \multicolumn{2}{|c|}{ CF } & \multicolumn{2}{|c|}{ AM1 } & \multicolumn{2}{|c|}{ AM2 } \\
\hline FAR $(\mathrm{g} / \mathrm{kg})$ & 0.0 & 4.0 & 8.0 & 4.0 & 8.0 & 4.0 & 8.0 \\
\hline Moisture (\%) & 12.00 & 12.69 & 12.99 & 12.01 & 12.93 & 11.70 & 12.01 \\
\hline Ash content (\%) & 3.23 & 3.43 & 4.85 & 2.83 & 3.96 & 3.51 & 5.88 \\
\hline Crude content (\%) & 3.33 & 2.48 & 4.02 & 3.31 & 3.58 & 3.31 & 5.26 \\
\hline Fat content $(\%)$ & 2.23 & 2.97 & 2.19 & 3.67 & 3.62 & 3.51 & 3.20 \\
\hline Protein content (\%) & 20.24 & 22.87 & 23.08 & 20.47 & 20.53 & 23.13 & 23.76 \\
\hline Carbohydrate (\%) & 57.97 & 55.56 & 52.87 & 57.89 & 55.38 & 55.20 & 49.89 \\
\hline Energy $\mathrm{KJ} / 100 \mathrm{~g}$ & 1393.56 & 1425.12 & 1354.21 & 1450.32 & 1407.38 & 1430.23 & 1353.75 \\
\hline
\end{tabular}

Data are means of triplicate determinations on dry weight basis.

FAR = fertilizer application rate; WAP = weeks after planting; CF = NPK fertilizer; AM1 = Pig manure, AM2 = Chicken manure

CK represents control where there is no application of fertilizer

Table 3: Nutritive value and food energy yield of Talinum triangulare grown with inorganic and organic fertilizers at different FARs at 12 WAP

\begin{tabular}{|c|c|c|c|c|c|c|c|}
\hline \multicolumn{8}{|l|}{ Nutritive value } \\
\hline Fertilizer type & $\mathrm{CK}$ & \multicolumn{2}{|c|}{ CF } & \multicolumn{2}{|c|}{ AM1 } & \multicolumn{2}{|c|}{ AM2 } \\
\hline FAR $(\mathrm{g} / \mathrm{kg})$ & 0.0 & 4.0 & 8.0 & 4.0 & 8.0 & 4.0 & 8.0 \\
\hline Moisture (\%) & 10.50 & 11.80 & 10.85 & 11.02 & 8.52 & 14.01 & 11.11 \\
\hline Ash content (\%) & 4.28 & 2.01 & 1.36 & 1.08 & 1.52 & 2.81 & 2.05 \\
\hline Crude content (\%) & 4.00 & 2.00 & 1.20 & 1.79 & 1.21 & 1.92 & 1.89 \\
\hline Fat content $(\%)$ & 3.85 & 4.41 & 3.11 & 3.92 & 3.96 & 3.99 & 4.07 \\
\hline Protein content (\%) & 24.32 & 18.13 & 17.41 & 18.06 & 15.25 & 21.52 & 18.09 \\
\hline Carbohydrate (\%) & 53.05 & 61.74 & 65.17 & 64.13 & 69.54 & 56.38 & 62.79 \\
\hline Energy KJ/100g & 1440.52 & 1503.48 & 1499.88 & 1523.87 & 1380.54 & 1454.67 & 1507.58 \\
\hline
\end{tabular}

Data are means of triplicate determinations on dry weight basis.

FAR = fertilizer application rate; WAP = weeks after planting; CF = NPK fertilizer; AM1 = Pig manure, AM2 = Chicken manure

CK represents control where there is no application of fertilizer 
Agric. Biol. J. N. Am., 2011, 2(12): 1437-1444

Table 4: Phytochemical composition $(\mathrm{mg} / 100 \mathrm{~g})$ of Telfaria occidentalis grown with inorganic and organic fertilizers at different FARs at 12 WAP

\begin{tabular}{|c|c|c|c|c|c|c|c|}
\hline \multirow{3}{*}{$\begin{array}{c}\text { Phytochemical } \\
\text { fertilizer type } \\
\text { FAR }(\mathrm{g} / \mathrm{kg})\end{array}$} & \multirow{3}{*}{$\begin{array}{l}\text { C.K } \\
0.0\end{array}$} & \multirow{2}{*}{\multicolumn{2}{|c|}{$\mathrm{CF}$}} & \multirow{2}{*}{\multicolumn{2}{|c|}{ AM1 }} & \multirow{2}{*}{\multicolumn{2}{|c|}{ AM2 }} \\
\hline & & & & & & & \\
\hline & & 4.0 & 8.0 & 4.0 & 8.0 & 4.0 & 8.0 \\
\hline Saponins\% & $\begin{array}{c}8.21 \\
\pm 0.20\end{array}$ & $\begin{array}{c}8.10 \\
\pm 0.10\end{array}$ & $\begin{array}{c}8.23 \\
\pm 0.10\end{array}$ & $\begin{array}{c}8.00 \\
\pm 0.12\end{array}$ & $\begin{array}{c}8.12 \\
\pm 0.10\end{array}$ & $\begin{array}{c}4.00 \\
\pm 0.20\end{array}$ & $\begin{array}{c}4.98 \\
\pm 0.11\end{array}$ \\
\hline Tannins\% & $<0.01$ & $<0.01$ & $<0.01$ & $<0.01$ & $<0.01$ & $<0.01$ & $<0.01$ \\
\hline Flavonoids\% & $\begin{array}{c}6.67 \\
\pm 0.10 \\
\end{array}$ & $\begin{array}{c}6.30 \\
\pm 0.20 \\
\end{array}$ & $\begin{array}{r}6.36 \\
\pm 0.1 \\
\end{array}$ & $\begin{array}{r}5.83 \\
\pm 0.11 \\
\end{array}$ & $\begin{array}{c}6.62 \\
\pm 0.20 \\
\end{array}$ & $\begin{array}{c}6.50 \\
\pm 0.10 \\
\end{array}$ & $\begin{array}{c}6.52 \\
\pm 0.10 \\
\end{array}$ \\
\hline Phenols\% & $\begin{array}{r}0.13 \\
\pm 0.1 \\
\end{array}$ & $\begin{array}{r}0.11 \\
\pm 0.3 \\
\end{array}$ & $\begin{array}{r}0.10 \\
\pm 0.1 \\
\end{array}$ & $\begin{array}{r}0.09 \\
\pm 0.2 \\
\end{array}$ & $\begin{array}{l}0.10 \\
\pm 0.1 \\
\end{array}$ & $\begin{array}{l}0.08 \\
\pm 0.2 \\
\end{array}$ & $\begin{array}{r}0.08 \\
\pm 0.3 \\
\end{array}$ \\
\hline Alkaloids\% & $\begin{array}{c}3.33 \\
\pm 0.20\end{array}$ & $\begin{array}{c}2.25 \\
\pm 0.10\end{array}$ & $\begin{array}{c}2.28 \\
\pm 0.20\end{array}$ & $\begin{array}{c}2.40 \\
\pm 0.11\end{array}$ & $\begin{array}{c}2.42 \\
\pm 0.10\end{array}$ & $\begin{array}{c}1.20 \\
\pm 0.10\end{array}$ & $\begin{array}{r}2.40 \\
\pm 0.11 \\
\end{array}$ \\
\hline
\end{tabular}

Data are means \pm standard deviation of triplicate determinations on dry weight basis.

FAR =fertilizer application rate; $\mathrm{WAP}=$ weeks after planting; $\mathrm{CF}=\mathrm{NPK}$ fertilizer; $\mathrm{AM} 1=$ Pig manure, $\mathrm{AM} 2$ = Chicken manure $\mathrm{CK}$ represents control where there is no application of fertilizer

Table 5: Phytochemical composition $(\mathrm{mg} / \mathbf{1 0 0 g})$ of Talinum triangulare grown with inorganic and organic fertilizers at different FARs at 12 WAP

\begin{tabular}{|c|c|c|c|c|c|c|c|}
\hline \multirow{3}{*}{$\begin{array}{c}\text { Phytochemical } \\
\text { fertilizer type } \\
\text { FAR }(\mathrm{g} / \mathrm{kg})\end{array}$} & \multirow{3}{*}{$\begin{array}{l}\text { C.K } \\
0.0\end{array}$} & \multirow{2}{*}{\multicolumn{2}{|c|}{ CF }} & \multirow{2}{*}{\multicolumn{2}{|c|}{ AM1 }} & & \\
\hline & & & & & & \multicolumn{2}{|c|}{ AM2 } \\
\hline & & 4.0 & 8.0 & 4.0 & 8.0 & 4.0 & 8.0 \\
\hline Saponins (\%) & $\begin{array}{c}6.23 \\
\pm 0.30\end{array}$ & $\begin{array}{c}4.30 \\
\pm 0.20\end{array}$ & $\begin{array}{c}6.00 \\
\pm 0.10\end{array}$ & $\begin{array}{c}5.60 \\
\pm 0.20\end{array}$ & $\begin{array}{c}6.20 \\
\pm 0.20\end{array}$ & $\begin{array}{c}4.00 \\
\pm 0.10\end{array}$ & $\begin{array}{c}4.35 \\
\pm 0.30\end{array}$ \\
\hline Tannins (\%) & $\begin{array}{c}0.15 \\
\pm 0.10\end{array}$ & $\begin{array}{c}0.18 \\
\pm 0.11\end{array}$ & $\begin{array}{c}0.20 \\
\pm 0.20\end{array}$ & $\begin{array}{c}0.17 \\
\pm 0.10\end{array}$ & $\begin{array}{c}0.19 \\
\pm 0.10\end{array}$ & $\begin{array}{c}0.15 \\
\pm 0.20\end{array}$ & $\begin{array}{c}0.17 \\
\pm 0.20\end{array}$ \\
\hline Flavonoids (\%) & $\begin{array}{c}3.42 \\
\pm 0.30\end{array}$ & $\begin{array}{c}3.24 \\
\pm 0.30\end{array}$ & $\begin{array}{c}3.33 \\
\pm 0.20\end{array}$ & $\begin{array}{c}3.33 \\
\pm 0.40\end{array}$ & $\begin{array}{c}3.51 \\
\pm 0.30\end{array}$ & $\begin{array}{c}3.40 \\
\pm 0.20\end{array}$ & $\begin{array}{c}3.13 \\
\pm 0.10\end{array}$ \\
\hline Phenols (\%) & $\begin{array}{c}0.10 \\
\pm 0.20\end{array}$ & $\begin{array}{c}0.09 \\
\pm 0.40\end{array}$ & $\begin{array}{c}0.10 \\
\pm 0.30\end{array}$ & $\begin{array}{c}0.11 \\
\pm 0.20\end{array}$ & $\begin{array}{c}0.11 \\
\pm 0.30\end{array}$ & $\begin{array}{c}0.08 \\
\pm 0.20\end{array}$ & $\begin{array}{l}0.07 \\
\pm 0.4\end{array}$ \\
\hline Alkaloids (\%) & $\begin{array}{c}2.09 \\
\pm 0.20\end{array}$ & $\begin{array}{c}1.23 \\
\pm 0.30\end{array}$ & $\begin{array}{c}1.30 \\
\pm 0.30\end{array}$ & $\begin{array}{c}1.27 \\
\pm 0.20\end{array}$ & $\begin{array}{c}1.32 \\
\pm 0.40\end{array}$ & $\begin{array}{c}1.17 \\
\pm 0.20\end{array}$ & $\begin{array}{c}1.28 \\
\pm 0.30\end{array}$ \\
\hline
\end{tabular}

Data are means \pm standard deviation of triplicate determinations on dry weight basis.

$\mathrm{FAR}=$ fertilizer application rate; WAP =weeks after planting; CF = NPK fertilizer; $\mathrm{AM} 1=$ Pig manure, $\mathrm{AM} 2=\mathrm{Chicken}$ manure

$\mathrm{CK}$ represents control where there is no application of fertilizer

\section{DISCUSSION}

The moisture content of Telfaria occidentalis increased with increase in inorganic and organic fertilizer application rates while in Talinum triangulare higher fertilizer application rates resulted in decrease in moisture content. Moisture content of Talinum triangulare recorded an increase in $4.0 \mathrm{~g} / \mathrm{kg}$ soil fertilizer application rate and a decreased in $8.0 \mathrm{~g} / \mathrm{kg}$ soil fertilizer application rate across the fertilizers as shown in Table 2. Further examination revealed that the highest moisture content was $14.01 \%$ in Talinum triangulare while Telfaria occidentalis recorded $12.99 \%$. This might be contribute to the highly perishable nature of the Talinum triangulare as reported by Akachukwu and Fawusi (1995) and Schuppers (2000). Although reports have shown that the moisture content of vegetables can be affected by season, the location of the plant and the stage of maturity. (Okwu and Morah, 2004; mepba et al, 2007). Ash content increased with increase in fertilizer application rate in Telfairia occidentalis while Talinum triagulare recorded a decrease in ash content across the fertilizer application rates. Crude fiber recorded an increase in $8.0 \mathrm{~g} / \mathrm{kg}$ soil fertilizer 
Agric. Biol. J. N. Am., 2011, 2(12): 1437-1444

application rate in Telfairia occidentalis while Talinum triagulare recorded a step-wise decrease across the fertilizer application rates of the various fertilizers. Fiber cleanses the digestive tract by removing potential carcinogens from the body and prevents the absorption of excess cholesterol (Mensah et al, 2008). Fibers also add bulk to the food and prevent the intake of excess starchy food and may therefore guard against metabolic conditions such as hypercholemia and diabetes mellitus (Mensah et al, 2008).

Fat content in Telfairia occidentalis increased at first fertilizer application but decreased in the second fertilizer application rate. Talinum triagulare showed increase in the $4.0 \mathrm{~g} / \mathrm{kg}$ and $8.0 \mathrm{~g} / \mathrm{kg}$ soil fertilizer application rates in all the various fertilizers except in the $8.0 \mathrm{~g} / \mathrm{kg}$ soil fertilizer application rate of those grown with chemical fertilizers These fatty acids in vegetables are known to increase membrane fluidity and allow for osmosis intracellular and extracellular gaseous exchange (Lovejoy, 2002).

Protein content increased in Telfaria occidentalis grown with the two fertilizer application rates while the protein content decreased in Talinum triangulare. Carbohydrate contents decreased significantly in Telfairia occidentalis while in Talinum Triangulare it increased across the two fertilizer application rates of the various fertilizers. Telfaria occidentalis showed step-wise increase in protein contents across the fertilizer application rates of the various fertilizers and decreased in fats and carbohydrate contents. On the other hand Talinum triangulare showed similar increase in fats and carbohydrate contents and decrease in protein contents across the fertilizer application rates of the various fertilizers. These findings also lent credence to Mnzava (1997) and Fasuyi (2006) who reported that nutrient content of different types of vegetables varies considerably and they are not major sources of carbohydrate compared to the starchy foods but contain vitamins, essential amino acids as well as minerals. Food energy yield of Telfaria occidentalis and Talinum triangulare grown with $4.0 \mathrm{~g} / \mathrm{kg}$ soil fertilizer application rate of the various fertilizers compared with the control soil showed the following order, pig manure > chicken manure > chemical fertilizers $>$ control soil and pig manure > chemical fertilizer $>$ chicken manure $>$ control soil respectively. Food energy yield recorded at $8.0 \mathrm{~g} / \mathrm{kg}$ soil fertilizer application rate compared with the control soil showed, pig manure >control soil > chemical fertilizer
$>$ chicken manure and pig manure, $>$ chicken manure $>$ chemical fertilizer > control soil for Telfaria occidentalis and Talinum triangulare respectively.

These results has demonstrated that using animal manures can promote the increase in food energy yield as compared with the treatment of chemical fertilizers.

Quantitative analysis of the phytochemical components of these vegetables studied showed no defined specific variations across the various fertilizers. This suggest that fertilizer applications may not have strong influence on the phytochemicals concentrations of vegetables. Saponins, flavonoids, phenols and alkaloids were identified in the sample extract of Telfaria occidentalis while tannins were below the detection limit of our method. Saponins, flavonoids, phenols, alkaloids and tannins were all identified in the sample extract of Talinum triangulare. These phytochemicals are of interest because they are important both for the plant, as defense compounds and for human, as a class of antioxidant and health promoting compounds. For instance, saponins have been reported to have hypocholesterolemic effect (Price et al 1987) and this may aid in the reduction of metabolic burden that would have been placed on the liver while flavonoid has anti-oxidation effect in animals (Enwere, 1998). These results suggest that the indigenous leaf vegetables require the urgent application of biotechnology, so that the phytochemical potentials of these vegetables can be fully exploited. Biotechnological approaches can selectively increase the amounts of defense compounds in crop plants thereby reducing the high costly and potentially toxic pesticides and increase the yield of some phytochemicals used as pharmaceuticals, flavor and perfumery material other natural products of commercial value.

\section{CONCLUSION}

The results obtained in this work suggest reduced amendment of agricultural soils with inorganic fertilizers but advocate the use of organic fertilizers. The results also showed that these leafy vegetables require urgent application of biotechnology, so that the nutritional and phytochemical potentials can be exploited. 


\section{REFERENCES}

Adeboye, O. C. FMD Ogbe, J. F. Bamidele (2003). Ethnobotany of Indigenous Leaf Vegetables of Southeasth Nigeria. Delpinoa, Italy. Vol 45: 295 - 299.

Adekunle, A.A and Ikumapayi (2006) Antifungal property and phytochemical screening of the crude extracts of funtumia elastica and mallotus oppositifolius. West Indian Med. J. 55 (4): 219.

Aiyeloja, A.A ${ }^{1}$ and Bello, O.A ${ }^{2}$ (2006) Ethnobotanical potentials of common herbs in Nigeria: A case study of Enugu State. Educational Research and Review (1), 16-22.

Akachukwu, C.O and Fawusi, M.O.A (1995). Growth characteristics, yield and nutritive of waterleaf, Talinum triangulare (jacq) wild in a semi-wild environment. Discovery and innovation, 7(2): 163-172.

Akang, E.N; Oremosu, A,A; Dosumu, O.O; Noronha, C.C. and Okanlawon, A.O.(2010). The effect of fluted pumpkin (Telfaria occidentalis) seed oil (FPSO) on testis and semen parameters. Agriculture and Biology Journal of North America. 1 (4) 697 - 703.

Akintayo, T. (1997), chemical composition and physicochemical properties of fluted pumpkin (Telfaria occidentalis) seed and seed oils. CODEN RISGAD 74 (1): 13-15.

Ano, A. O. (2000). Use of Urban and Agricultural waste as soil amendments in root and tuber crops production in Southern Nigeria, In: Food and fiber production. I. C Nwaigbo, U. H. Ukpabi and A. Anene edns proceedings if Abia State University Uturu Nigeria pp $298-303$.

AOAC (1990) Association of Official Analytical Chemists. Official methods of analysis $15^{\text {th }}$ ed. Washington DC.

APHA (1998). American Public Health Association. Standard methods for examination of water and waste water. Washington D. C. 29pp.

ASTM (1999). American society for testing and materials. Official document on methods of testing all types of $m$ aterials. Washington D.C. 29pp.

Ayitey-Smith, E. and Addae-Mensah (1977). A preliminary pharmacological study (1977) Winnine:, A piperine type of alkaloid from the roots of piper guineense. W. Afr. J pharmacol. Drug Res. 4: 7-8.

Benso, A and Adeyemo, S.O (2007). Evaluation of antibacterial properties of tannins isolated from Dichrostachys cinerea, Afr. J. Biotechnol. 6 (15): 17851787.
Bensoussan, K; Morales, C. and Hermo L. (1998). Vitamin $\mathrm{E}$ deficiency causes incomplete spermatogenesis and affects the structural differentiation of epithelial cells of the epididymis in the rat. Journal of Andrology, 19 (3): 266-288.

Buchanan, B. B., Gruissem, W. and Jones, R. C. (2000). Biochemistry and Molecular Biology of Plants. $1^{\text {st }}$ Edition. I. K International Pvt Limited Indian.

Enwere, N.J (1998). Foods of plants origin in Enugu Nsukka. Afroobis publication, 736-741.

Fasuyi, A.O (2006). Nutritional potentials of some tropical vegetable leaf meals: chemical characterization and functional properties. Afr. J. biotechnol. 5 (1): 49-53

Gill, L.S (1992). Ethnobotanical uses of plants in Nigerial. University of Binin press, Binin City, 350.

Glenvillile, M (2006). The foundation of health: discover the fundamentals of a healthy life. www. Natural health practice/Ebooks c79 cfm. Accessed 29/04/10.

Harborne, J.B (1973) phytochemical methods Chapman and Hall London, 113

James, S.C.(1995). The analytical chemistry of foods. Blackie, London, 20-25.

Kubmarawa, D. Ajoku, G. A., Enwerem, N. M., Okorie, D. A. (2007). Preliminary phytochemical and antimicrobial screening of 50 medicinal plants from Nigeria. Afr. J. Biotechnol. 6 (14): 1690 - 1696.

Liu, R.H (2004) potential synergy of phytochemicals in cancer prevention: mechanism of action. J. Nutrition. 134: 34795-34855.

Lovejoy, J.C. (2002). The influence of dietary fats in insulin resistance current diabetes reports. 2 (5): 430-440.

Mensah, J.K; Okoli, R.I; Ohaju-Obodo, J.O and Eifediyi, K (2008) phytochemical, nutritional and medicinal properties of some leafy vegetables consumed by Edo people in Nigeria. African Journal of Biotechnology 7 (14), 2304-2309.

Mepba, H. D., Eboh, L. and Banigo, D. E. B. (2007). Effects of processing treatments on the nutritive composition and consumer acceptance of some Nigerian edible leafy vegetables. African Journal of food Agriculture, Nutrition and Development 7(1) 1 - 18.

Mnzava, N.A (1997). Comparing nutritional vaules of exotic and indigenous vegetables. Limbe Cameroon, January 1997. Schippers, R.R; Budd, L (eds). Chatham.UK; NRI/ IPGRI/CPRO workshop. 
Mosha, T.C and Gaga, H.E. (1999). Nutritive value and effect of blanching on trypsin and chymotrypsin inhibitor activities of selected leafy vegetables. Plant foods for Human Nutrition 54:271-283.

NIS (2004). Nigerian industrial standard. Standard for white bread. Approved by Standard Organization of Nigeria.

Nwaigbo, I.C; Ukpabi, U.H. and Anene, A. edns proceedings if Abia State University Uturu Nigeria pp 298-303.

Obadoni, B.O and Ochuko, P.O (2001) phytochemical studies and comparative efficacy of the crude extracts of some homeostatic plants in Edo and Delta State of Nigeria. Global J. Pure and Applied Sciences, 8: 203208.

Okwu, D.E (2005) phytochemicals, vitamins and mineral content of two Nigeria medicinal plants. International Journal of Molecular and Advance Sciences 1(4): 375381 ,

Okwu, D. E. \& Morah, F. N. I. 2004. Mineral and Nutritive value of Dennettia tripetala fruits. Fruits 59, $437-442$.

Onwuka G.I (2005). Food analysis and instrumentation, theory and practical. $1^{\text {st }}$ edition Naphtha Prints Lagos Nigeria $89-98$.

Opadode, J.T. and Adebooye, O.C (2005) Application of biotechnology for the improvement of Nigeria indigenous leaf vegetables. Journal of Biotechnology 4 (3), 138-142.
Opera-Nadi, A.O and Okwe, A.O.(2000) combined effects of inorganic fertilizer and organic materials on soil properties and growth of maize on an utisol in Southern Nigeria; In food and fiber production in Nigeria edns. Nwaigbo, I.C;

Osborn, D.R and Voogt, P. (1978). Calculations of calorific value in the analysis of nutrients in roots. Academic press, New York pp 239-240.

Pallant J. (2002). SPSS survival Manual; A step by step guide to data analysis using SPSS. $1^{\text {st }}$ edition. Bell and Bain Ltd, Glasgow.

Price, K; Johnson, R. and Federick, H. (1987). The chemical and biological significant of saponins in food and feeding stuffs. Critical Ravager in food. Sci. Nutr. 26: 127-135.

Rangari, V. D. (2008). Pharmacognosy and Phytochemistry Vol. $12^{\text {nd }}$ Edition Career Publishers. India.

Schipper, R. R. (2000). African indigenous vegetable-An overview of the cultivated species. Chatham, UK: $\mathrm{NRI} / \mathrm{CAT} .231$

Schipper, R. R. and Buddy, L. (1994). African indigenous vegetables proceedings of the $\mathrm{NRI} / \mathrm{IPGRI} / \mathrm{CPRO}$ workshop, $13-28^{\text {th }}$ Jan 1997. Limbe, Cameroon. ODA, Uk.

Van-Burden, T.P and Robinson, W.C (1981) formation of complexes between protein and tannin acid. J. Agric Food Chem., 1: 77-82. 